\title{
Elementen van preventie
}

\author{
Mathieu Roelants
}

Published online: 14 juli 2021

(C) Bohn Stafleu van Loghum is een imprint van Springer Media B.V., onderdeel van Springer Nature 2021

De vaccinatiecampagne tegen het coronavirus illustreert nog maar eens de delicate balans tussen keuzevrijheid en aanvaarding waar nagenoeg alle preventieprogramma's mee te maken hebben. Het verschil bij deze vaccinatiecampagne is dat het succes ervan afhangt van het bereik. Hoewel vaccinatie ook het individu beschermt tegen (ernstige) ziekte, moeten we er wel met zijn allen (of toch voldoende velen) voor kiezen om de epidemie te bestrijden. De preventie van niet-overdraagbare ziekten steunt in de meeste gevallen wél op inperking van het individuele risico, maar heeft verder ook raakvlakken met vaccinatiecampagnes.

In dit nummer komen vier elementen aan bod die kunnen bijdragen aan een succesvolle preventie. In de eerste plaats is het noodzakelijk om de doelgroep te informeren. In een onderzoek van Femke van der Boon bleek dat ouders vaak helemaal niet op de hoogte waren van het nut van vroege introductie van allergenen via de voeding bij hun (jonge) kind. Het informeren van jonge ouders zou alvast deze belemmering (dat wil zeggen onwetendheid) kunnen wegnemen. Ook in het onderzoek naar redenen waarom jongeren wel of niet worden gevaccineerd tegen meningokokken type ACWY door Van den Heuvel en collega's komt de vraag naar informatie en advies door een neutrale instantie naar voren.

Dit laatste onderzoek brengt ons tevens bij het tweede element: het wegnemen van twijfel door antwoord te bieden op al dan niet terechte zorgen. Het zal $\mathrm{u}$ niet verbazen dat ouders meer bezorgd waren over de meningokokkeninfectie en over de eventuele bijwerkingen van de vaccinatie, en dat jongeren zich vooral zorgen maakten over de prik. Dit lijkt een haast onschuldige bevinding, gelet op de buitenissige theorieën die nu opduiken in het maatschappelijk debat, maar interessant is dat Van den Heuvel en collega's hun veldwerk enkele maanden voor de start van de pandemie hebben uitgevoerd. Wel opletten met het weerleggen van al te marginaal gedachtegoed, want onderzoek uit de communicatiewetenschappen leert dat $\mathrm{u}$ het op die manier kan legitimeren, en dat is natuurlijk niet de bedoeling.

Een derde element is het verzekeren en optimaliseren van toegang tot het programma of zorg. In de GGD Gelderland-Midden werd de invoering van een digitaal afsprakenportaal aangegrepen om het effect op de opkomst en het bereik te onderzoeken. Dergelijke veranderingen zijn bij uitstek het moment om nieuwe maatregelen of methoden te onderzoeken, zoals wordt geïllustreerd in het onderzoek van Den Hertog-Kuijl en collega's. Ten slotte is het belangrijk om het beoogde effect in de doelgroep te monitoren. Paula van Dommelen en Ondine Engelse onderzochten de prevalentie van borstvoeding aan de hand van data uit het Digitaal Dossier van de Jeugdgezondheidszorg via Jeugd in Beeld. Dit onderzoek illustreert mooi hoe bestaande data het mogelijk maken om relevante en niet vertekende indicatoren te berekenen, maar laat helaas ook zien dat het starten met borstvoeding beter kan. Het werk zit er dus nog niet op!

Mathieu Roelants

\section{Roelants $(\bowtie)$}

Omgeving en Gezondheid, KU Leuven, Leuven, België

mathieu.roelants@kuleuven.be 